\title{
Meningkatkan kemampuan membaca permulaan menggunakan model direct instruction berbantuan media kartu kata bergambar
}

\author{
Siti Asmonah \\ TK Aisyiyah Pembina Banguntapan. Petet, Potorono, Banguntapan, Bantul, 55792, Indonesia \\ E-mail: sitiasmonah6@gmail.com
}

\begin{tabular}{|c|c|}
\hline ARTICLE INFO & ABSTRACT \\
\hline $\begin{array}{l}\text { Article history: } \\
\text { Received: } 14-8-2019 ; \\
\text { Revised: } 20-8-2019 ; \\
\text { Accepted: } 24-8-2019 \\
\text { Keywords: } \\
\text { membaca permulaan; Direct } \\
\text { Instruction; media kartu } \\
\text { kata bergambar; early } \\
\text { reading skill; Direct } \\
\text { Instruction; picture word } \\
\text { card }\end{array}$ & 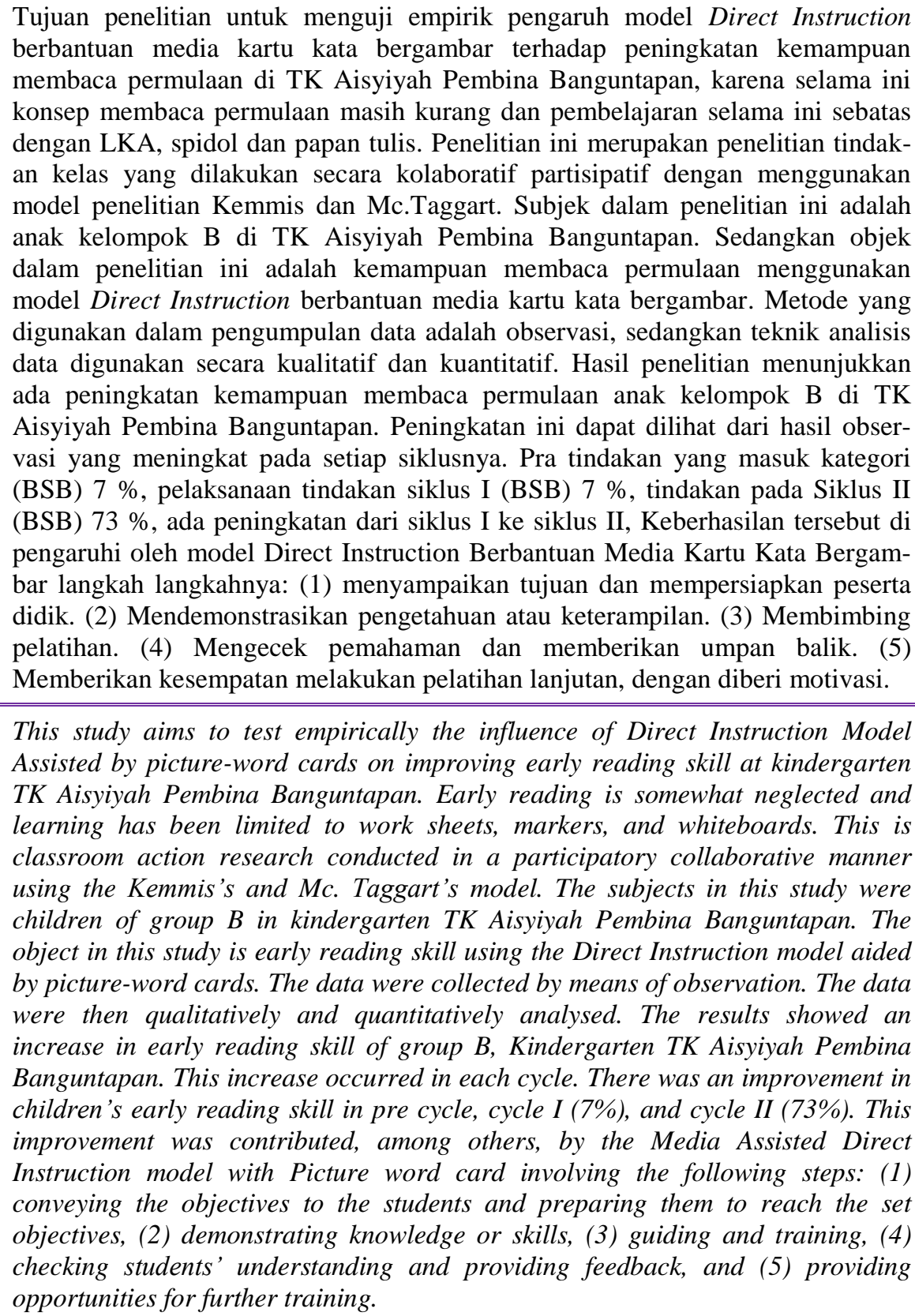 \\
\hline
\end{tabular}

\section{PENDAHULUAN}

Usia dini merupakan masa keemasan (golden age), oleh karena itu pendidikan pada masa dini 
merupakan pendidikan yang sangat fundamental dan sangat menentukan perkembangan selanjutnya. Masa ini juga merupakan masa peletak dasar pertama untuk mengembangkan kemampuan kognitif, afektif, psikomotorik, bahasa, sosial emosional, dan moral agama anak. Pada masa ini anak sangat membutuhkan stimulasi dan rangsangan dari lingkungannya. Apabila anak mendapatkan stimulus yang baik, maka aspek perkembangan anak akan berkembang secara optimal.

Hal ini tertuang di dalam Undang-Undang No. 58 Tahun 2009 Tentang Standar Pendidikan Anak Usia Dini bahwa ada lima aspek perk embangan yang harus dikembangkan pada anak yaitu meliputi perkembangan moral agama, fisik motorik, kognitif, bahasa, dan sosial emosional. Dari kelima aspek perkembangan tersebut, perkembangan bahasa menjadi penting karena dengan berbahasa anak akan mampu mengutarakan keinginannya dan dapat berkomunikasi dengan orang lain yang ada di sekitarnya.

Peraturan Menteri Pendidikan Pendidikan dan Kebudayaan RI No 137 tahun 2013 tentang Standar Pendidikan Anak Usia Dini bahwa lingkup perkembangan keaksaraan anak usia 5-6 tahun tingkat pencapaian perkembangan keaksaraan anak meliputi menyebutkan simbol-simbol huruf yang dikenal, mengenal suara huruf awal dari nama benda-benda yang ada disekitarnya, menyebutkan kelompok gambar yang memiliki bunyi /huruf awal yang sama, dan memahami hubungan antara bunyi dan bentuk huruf. Oleh sebab itu kemampuan berbahasa anak harus distimulus sejak dini, sejak usia prasekolah keterampilan berbahasa dan berkomunikasi dibiasakan dan dilatih dengan baik dan benar.

Pembelajaran kemampuan membaca permulaan sangat penting untuk diajarkan pada anak usia dini, karena dapat membaca akan mempengaruhi pengembangan bahasa pada sekolah jenjang selanjutnya. Sekolah Dasar biasanya mengadakan tes atau seleksi untuk calon muridnya. Dapat membaca adalah tes yang harus dilakukan anak sebelum masuk ke Sekolah Dasar terbaik di daerah manapun, sehingga menyebabkan para orang tua murid menuntut sekolah agar anaknya dapat membaca sejak dini. Dengan demikian pendidik TK berusaha menggunakan metode dan media yang tepat, menyenangkan dan tidak membebani anak dalam pembelajaran.

Pengembangan kemampuan membaca permulaan tidak lepas dari esensi belajar anak usia dini yaitu belajar melalui bermain. Permainan yang diberikan memiliki nilai edukatif yang dapat mengembangkan aspek kemampuan membaca permulaan secara efektif dan optimal sehingga menunjukkan perilaku senang membaca buku terhadap buku-buku yang dikenali. Sesuai dengan Standar Tingkat Pencapaian Perkembangan Anak dalam Bidang Pengembangan Bahasa untuk anak usia 5-6 tahun.

Dengan menggunakan model Direct Instruction berbantuan media kartu kata bergambar sebagai media pembelajaran diharapkan mampu meningkatkan kemampuan membaca permulaan dengan bermain, anak belajar tentang negosiasi, berkomunikasi, sudut pandang, pikiran dan perasaan orang lain. Sehingga dapat merangsang minat anak dalam belajar dan dapat mengembangkan kemampuan membaca permulaan. Di dukung dengan media kartu kata bergambar dengan ukuran yang lebih besar dan bervariasi akan menarik perhatian siswa, dan bentuk kegiatannya yang menantang, akan lebih efektif dan membuat anak menjadi senang.

\section{Pengertian kemampuan membaca permulaan}

Bahasa adalah suatu bentuk komunikasi baik itu lisan, tertulis atau isyarat yang berdasarkan pada suatu system dari symbol-simbol. Sedangkan berbahasa anak adalah suatu cara yang dimiliki anak untuk mengungkapkan perasaan kepada orang lain. Ungkapan yang disampaikan berupa tulisan yang di lafalkan yaitu dengan membaca. Dalam Kamus Besar Bahasa Indonesia (2005) diartikan bahwa, sesuatu yang tertulis kemudian menuturkan serta menyebutkan kembali apa yang tertulis dinamakan membaca (Hasan, 2005). Dalam Permendiknas No 58 Tahun 2009 kegiatan membaca untuk anak usia dini masuk dalam lingkup perkembangan bahasa keaksaraan. Yang terdiri dari: (1) Anak akan belajar untuk mengenal simbol-simbol huruf; (2) Menyebutkan nama benda yang suara huruf awalnya sama; (3) Menyebutkan kata yang mempunyai huruf awal yang sama; (4) Memahami hubungan antara bunyi dan bentuk huruf dengan membaca gambar atau menghubungkan tulisan dengan symbol; (5) Serta membaca dan menulis namanya sendiri dengan lengkap.

Dalam kemampuan membaca permulaan untuk anak usia dini, di mulai dengan mengenal huruf, kata, kalimat-kalimat sederhana. Darwadi (2002) bahwa: langkah pertama melatih keterampilan membaca ditekankan pada simbol-simbol atau tanda- tanda yang berhubungan dengan huruf- huruf. Kegiatan kemampuan membaca permulaan masih lebih ditekankan pada pengenalan dan 
Siti Asmonah

pengucapan lambang- lambang bunyi yang berupa huruf, kata, dan kalimat dalam bentuk sederhana. Tujuan pengembangan bahasa kanak-kanak (1) Memahami bahasa reseptif (menyimak dan membaca); (2) Memahami bahasa ekspresif (mengungkapkan bahasa secara verbal dan nonverbal); (3) Mengenal keaksaraan awal melalui bermain

Dengan demikian ada beberapa alasan mengapa kita perlu menumbuhkan kemampuan membaca permulaan pada anak, alasan tersebut adalah: (1) Anak yang senang membaca akan membaca dengan baik, sebagian besar waktunya akan digunakan untuk membaca; (2) Anak-anak yang gemar membaca akan mempunyai rasa kebahasaan yang lebih tinggi. Mereka akan berbicara, menulis, dan memahami gagasan-gagasan rumit secara lebih baik. Membaca akan memberikan wawasan yang lebih luas dalam segala hal dan membuat belajar lebih mudah. Membaca akan membantu kepada anak memiliki rasa kasih saying. Anak-anak yang gemar membaca dihadapkan pada suatu dunia yang penuh dengan kenungkinan dan kesempatan.

\section{Lingkup Perkembangan Kemampuan Membaca Permulaan Pada Anak TK}

Anak usia Taman Kanak-kanak memiliki kemampuan membaca dan menulis. Dasar kemampuan membaca permulaan yang dimiliki anak usia taman kanak-kanak dapat dilihat melalui kemampuan anak dalam melakukan koordinsi gerakan visual dan motorik. Kemampuan kosakata anak usia 5 tahun memiliki 1900-2150 kosa kata, dan usia 5 tahun 6 bulan memiliki 2150-2500 kosa kata.

Proses kemampuan membaca permulaan untuk anak usia dini dilakukan melalui pengenalan simbol-simbol atau lambang huruf. Lambang huruf tersebut dipelajari satu persatu, yang kemudian dirangkai menjadi kata-kata. Ketika anak dapat merangkai kata, maka anak lambat laun akan mengetahui makna dari rangkaian kata dan selanjutnya mampu memahami gabungan kata menjadi kalimat sederhana. secara bertahap gabungan kata-kata yang ditulis dapat dibaca dengan arah kiri ke kanan, jarak dipakai untuk memisahkan kata atau huruf. Proses membaca juga sangat dipengaruhi oleh dukungan dan interaksi dari lingkungan. Pengalaman langsung merupakan cara belajar anak dalam menyerap suatu pengetahuan.

\section{Tahap-tahap Perkembangan Kemampuan Membaca Permulaan}

Menurut Aulia, (2011) menuturkan keterampilan pertama dalam membaca diperoleh dari keterampilan sebelumnya. Tahapan perkembangan kemampuan membaca permulaan, yaitu: Tahap dasar (0), tahap 1, tahap 2, tahap 3, tahap 4.

Pada tahap dasar ditandai ketika anak mulai menguasai prasyarat membaca dan membedakan huruf dalam alphabet. Kemudian anak dapat membaca beberapa kata yang sering ditemui seperti di televisi atau media lainnya. Hal ini dapat dikatakan bahwa anak sudah dapat membedakan antara pola huruf meskipun belum dapat mengerti kata itu sendiri. Tahap 1 terjadi pada tahun pertama sekolah, anak belajar kecakapan merekam fonologi yang digunakan untuk menerjemahkan simbol-simbol ke dalam suara dan kata-kata. Tahap 2, Anak sudah belajar membaca dengan fasih dan menguasai hubungan dari huruf ke suara serta dapat membaca sebagian besar kata dan kalimat sederhana. Pada tahap 3, anak sudah bisa mendapatkan informasi dari materi yang tertulis. Anak akan belajar dari buku yang mereka baca. Pada tahap 4, kemampuan membaca anak sudah sangat fasih. Anak menjadi semakin memahami beragam materi bacaan dan menarik kesimpulan dari apa yang ia baca.

Kemampuan membaca permulaan untuk anak berlangsung dalam beberapa tahapan sebagai berikut: (1) Tahap Fantasi (magical stage), yaitu anak mulai belajar menggunakan buku, melihat dan membalik lembaran buku atupun membawa buku kesukaannya. Tahap Pembentukan konsep diri (self-concept stage), yaitu Anak mulai memandang dirinya sebagai 'pembaca' terlihat keterlibatan anak dalam kegiatan membaca, berpura-pura membaca buku, memaknai gambar berdasarkan pengalaman yang diperoleh sebelumnya, dan menggunakan bahasa baku yang tidak sesuai dengan tulisan; (3) Tahap membaca gambar (bridging reading stage), yaitu anak mulai tumbuh kesadaran akan tulisan dalam buku dan menemukan kata yang pernah ditemui sebelumnya, dapat mengungkapkan kata-kata yang bermakna dan berhubungan dangan dirinya, sudah mengenal tulisan kata-kata puisi, lagu, dan sudah mengenal abjad; (4) Tahap pengenalan bacaan (take off reader stage), anak mulai menggunakan tiga sistem isyarat (graphoponik, sematik, dan sintaksis). Juga sudah mulai tertarik pada bacaan, dapat mengingat tulisan dalam konteks tertentu, berusaha mengenal tanda-tanda pada lingkungan, serta membaca berbagai tanda seperti pada papan iklan, kotak susu, pasta gigi dan lainnya. Dan (5) Tahap membaca lancar (independent reader stage), yaitu anak dapat membaca berbagai jenis buku 
Siti Asmonah

secara bebas. Orang tua dan guru masih harus tetap membacakan buku pada anak. Tindakan tersebut dimaksudkan dapat mendorong anak untuk memperbaiki bacaannya. Bantu anak memilih bacaan yang sesuai.

Pendapat-pendapat tersebut dapat disimpulkan bahwa dalam penyampaian pembelajaran dalam kemampuan membaca permulaan harus sesuai dengan tahap perkembangan. Tahapan anak berbedabeda walaupun umurnya sama, tergantung dari kesiapan anak. Apabila anak belum siap untuk belajar membaca, jangan dipaksakan untuk membaca. Pendidik

/orangtua harus mengenal tahapan membaca peserta didik atau anaknya.

\section{Karakteristik Kemampuan Membaca Permulaan Anak 5-6 Tahun}

Menurut Rubin (Dewi, 2012) pembelajaran membaca yang paling utama yaitu pembelajaran yang landasi pada kepentingan anak dan memperhitungkan sesuatu yang dimiliki anak. Anak usia TK sudah dalam kemampuan membaca permulaan, yaitu: (1) Difokuskan pada peningkatan kemampuan anak mengucapkan bunyi-bunyi bahasa. Anak yang mengalami kesulitan dalam mengucapkan bunyi tertentu perlu dilatih secara terpisah; (2) Menyadarkan anak bahwa kata dibentuk oleh fonem atau bunyi yang membedakan; (3) Menghubungkan tulisan dengan simbol atau gambar yang melambangkannya. Anak yang mengalami kesulitan dalam hal hubungan bunyi huruf maka pengajaranya secara terpisah; (4) Membedakan bunyi-bunyi merupakan kemampuan yang penting dalam pemerolehan bahasa, khususnya membaca; (5) Kemampuan mengingat yang dimaksud lebih mengarah pada kemampuan untuk menilai apakah dua bunyi atau lebih itu sama atau berbeda; (6) Membedakan huruf-huruf (lambang bunyi). Jika anak masih kesulitan membedakan huruf, berarti ia belum siap untuk membaca; (7) Kegiatan membaca dalam bahasa Indonesia menggunakan sistem dari kiri ke kanan; (8) Perkembangan kognitifnya juga mengalami kesulitan dalam membaca, sebab membaca pada dasarnya merupakan kegiatan berpikir.

Anak yang siap belajar membaca tentunya sudah memiliki kematangan emosi yang baik. Hal ini tentunya didukung oleh penyesuaian diri yang dapat dilakukan anak dengan lingkungan di mana anak belajar. Ditandai dengan adanya rasa percaya diri yang muncul dari dalam diri anak. Berdasarkan beberapa pendapat tersebut, maka faktor yang sangat mempengaruhi dalam penelitian ini adalah faktor lingkungan dan faktor psikologis.

Lingkungan yang dipersiapkan dapat menstimulasi anak-anak berpartisipasi dalam kegiatan belajar dengan optimal dalam hal ini media kartu kata bergambar sangat membantu keberhasilan dalam meningkatkan kemampuan membaca permulaan. Dengan bentuk kartu yang mempunyai ukuran lebih besar, didukung warna yang menarik, dan tehnik penyampaian kartu kata bergambar yang bervariasi, sehingga nuansa pembelajaran lebih efektif dan menyenangkan.

\section{Model Pembelajaran Direct Instruction}

Pembelajaran langsung (Direct Instruction) suatu model pembelajaran yang bersifat berpusat pada guru. Dalam menerapkan model pembelajaran langsung guru harus mendemonstrasikan pengetahuan atau keterampilan yang dilatihkan kepada siswa secara langkah demi langkah.

Pembelajaran langsung dirancang untuk penguasaan pengetahuan prosedural maupun keterampilan. keunggulan terpenting dari pembelajaran langsung adalah adanya fokus akademik, arahan dan control guru, harapan yang tinggi terhadap perkembangan siswa, sistem manajemen dan atmosfer akademik yang relatif stabil. Pembelajaran langsung dimaksudkan untuk menuntaskan dua hasil belajar penguasaan pengetahuan yang distrukturkan dengan baik dan penguasaan keterampilan. Adapun fase pembelajaran langsung sebagai berikut: (1) Fase 1, Estabilishing Set: menyampaikan tujuan dan mempersiapkan peserta didik, Guru menjelaskan tujuan pembelajaran, informasi latar belakang pembelajaran, mempersiapkan peserta didik untuk belajar; (2) Fase 2, Demonstrating: mendemonstrasikan pengetahuan atau keterampilan, Guru mendemonstrasikan keterampilan yang benar, menyajikan informasi tahap demi tahap; (3) Fase 3, Guided Practice: membimbing pelatihan, Guru merencanakan dan memberi pelatihan awal; (4) Fase 4, Feed Back: mengecek pemahaman dan memberikan umpan bali, Guru mengecek apakah peserta didik telah berhasil melakukan tugas dengan baik dan memberi umpan balik; (5) Fase 5, Extended Practice: memberikan kesempatan melakukan pelatihan lanjutan, dengan perhatian khusus pada penerapan kepada situasi lebih kompleks dalam kehidupan sehari-hari. 
Siti Asmonah

\section{Media Kartu Kata Bergambar}

Media merupakan serapan bahasa latin serta kata jamak dari "medium" memiliki makna perantara, perantara dari asal pesan dan penerima pesan. (a receiver) (Eliyawati, 2005). Lebih lanjut disampaikan dengan media dalam pembelajaran, maka anak akan mudah untuk menerima pelajaran yang diberikan guru karena akan timbul motivasi dan pembelajaran akan menjadi lebih menarik. Media adalah segala sesuatu yang dapat digunakan untuk menyalurkan pesan dari pengirim ke penerima, sehingga dapat merangsang pikiran, perasaan, perhatian dan minat si penerima pesan.

Badan Pengembangan dan Pembinaan Bahasa, Kamus Bahasa Indonesia untuk Pelajar (2011), keberhasilan Media Kartu kata Bergambar dalam mencocokan kartu yaitu medium yang bermanfaat mempersempit pilihan, menjelaskan standar atau menentukan apa yang menjadi prioritas. Huruf alphabet adalah sebuah sistem tulisan yang berdasarkan lambang fonem vokal dan konsonan yang terdiri dari huruf (a) sampai huruf (z). Jadi kartu kata bergambar adalah kartu yang berisi kata-kata dan terdapat gambar.Kartu kata bergambar ini akan menjadi media yang nantinya saat pembelajaran, siswa akan menemui macam-macam kartu yang berbeda tulisan serta gambarnya. Dan dalam penggunaannya bisa divariasikan dengan kartu kalimat dan kartu huruf.

Dapat diambil kesimpulan bahwa menggunakan Model Direct Instruction berbantuan media kartu kata bergambar adalah Pembelajaran langsung (Direct Instruction) suatu model pembelajaran yang bersifat berpusat pada guru. Dalam menerapkan model pembelajaran langsung guru harus mendemonstrasikan pengetahuan atau keterampilan yang dilatihkan kepada siswa secara langkah demi langkah dengan dengan di bantu media /peraga pada pembelajaran baca tulis huruf alphabet yang berbentuk kartu bergambar yang berfungsi untuk menyampaikan informasi kepada siswa yang berupa huruf vokal dan konsonan dan bagaimana cara membaca yang baik dan benar serta menstimulasi siswa, memperkuat daya ingat dan kemampuan berfikir siswa. Kegunaan kartu kata bergambar sebagai berikut: (1) Dapat membaca pada usia dini; (2) Mengembangkan daya ingat otak kanan; (3) Melatih kemampuan konsentrasi balita; (4) Memperbanyak perbendaharaan kata dari balita; (5) Sedang kelebihannya adalah: (a) Mudah dibawa ke mana-mana; (b) Dapat disimpan dimanapun, sehingga tidak membutuhkan ruang yang luas, dan digunakan dimana saja; (c) Praktis dalam membuat dan menggunakannya, sehingga kapan pun anak didik bisa belajar dengan baik menggunakan media ini; (d) Biaya pembuatan media ini juga sangatlah murah, karena dapat menggunakan barangbarang bekas seperti kardus; (e) Gampang diingat karena kartu ini bergambar yang sangat menarik perhatian; (f) Sehingga kartu ini akan memudahkan siswa untuk mengingat dan menghafal bentuk huruf-huruf tersebut; (g) Menyenangkan sebagai media pembelajaran, bahkan bisa digunakan dalam permainan. Misalnya siswa secara berlomba-lomba mencari satu kartu kata yang disusun secara acak yang kemudian harus dipasangkan sesuai antara tulisan (kata) dengan gambarnya. Cara seperti ini juga bisa mengasah aspek kognitif dan motorik kasar anak.

\section{METODE}

Penelitian meningkatkan kemampuan membaca permulaan menggunakan model direct intruction berbantuan media kartu kata bergambar dilaksanakan pada semester ganjil Tahun pelajaran 2017/2018 mulai bulan Agustus sampai dengan November Tahun 2018. Adapun tempat pelaksanaan di TK Aisyiyah Pembina Banguntapan yang beralamat di dusun Petet Potorono Banguntapan Bantul Yogyakarta, di Kelompok B3 dengan jumlah siswa 15 orang yang terdiri dari 10 putra dan 5 putri. Penelitian ini menggunakan desain penelitian dari Kemmis dan Mc Taggart. Dalam penelitian ini adalah model siklus yang dilakukan secara berulang dan berkelanjutan atau proses pembelajaran yang semakin lama semakin meningkat hasilnya.

Jenis data yang dikumpulkan adalah data kuantitatif dan data kualitatif. Cara pengambilan data tentang keterlaksanaan kegiatan pembelajaran dengan model pembelajaran Direct Instruction berbantuan media kartu kata bergambar diperoleh dari skenario pembelajaran dan hasil observasi aktivitas guru dan aktivitas anak. Data hasil penelitian akan dianalisis secara deskriptif. Hal ini bermanfaat untuk rencana perbaikan pembelajaran

Indikator keberhasilan, Terlaksananya model pembelajaran Direct Instruction berbantuan media kartu kata bergambar pada pembelajaran TK selama penelitian dan Adanya peningkatan kemampuan membaca permulaan pada model pembelajaran Direct Instruction berbantuan media kartu kata bergambar yaitu minimal 70\% pada kriteria Berkembang Sangat Baik. 
Siti Asmonah

\section{HASIL DAN PEMBAHASAN}

Tabel 1. Perbandingan Persentase Peningkatan Melaksanakan Model Pembelajaran Direct Instruction Berbatuan Media Kartu Kata Bergambar, Pra penelitian /Sebelum penelitian, Sesudah Pelaksanaan Peneleitian I, dan Sesudah Pelaksanaan penelitian ke II

\begin{tabular}{llccc}
\hline \multirow{2}{*}{ No. } & \multirow{2}{*}{ Indikator Keberhasilan } & Pra Penelitian & Penelitian Ke I & \multicolumn{2}{c}{ Penelitian ke II } \\
\cline { 2 - 4 } & & Prosentase & Prosentase & Prosentase \\
\hline 1. & Belum Berkembang & $60 \%$ & $51 \%$ & $0 \%$ \\
2. & Mulai Berkembang & $20 \%$ & $27 \%$ & $8 \%$ \\
3. & Berkembang Sesuai Harapan & $13 \%$ & $14 \%$ & $19 \%$ \\
4. & Berkembang Sangat Baik & $7 \%$ & $8 \%$ & $73 \%$ \\
\hline
\end{tabular}

Berdasarkan tabel 1 dapat diketahui adanya peningkatan kemampuan membaca permulaan dari Pra tindakan ke sesudah pelaksanaan tindakan pada Siklus I serta peningkatan dari Siklus I ke Siklus II, data yang diperoleh dari jumlah 15 anak. Ada peningkatan hasil pada indikator Berkembang Sangat Baik (BSB) di mulai dari Pra tindakan ke sikllus I ada peningkatan $1 \%$, kemudan $65 \%$, sedangkan pada indikator Berkembang sesuai Harapan (BSH) di mulai dari para tindakan ke siklus I ada peningkatan $1 \%$ dari Siklus I ke Siklus II ada peningkatan 5\% ,sedangkan indikator Mulai Berkembang (MB) dari pra tindakan ada peningkatan $7 \%$ pada siklus II ada Penurunan yang semula pada siklus I $27 \%$ menjadi $8 \%$ artinya dari 15 anak pada siklus II tinggal $8 \%$ yang mulai berkembang dan yang belum berkembang sudah tidak ada

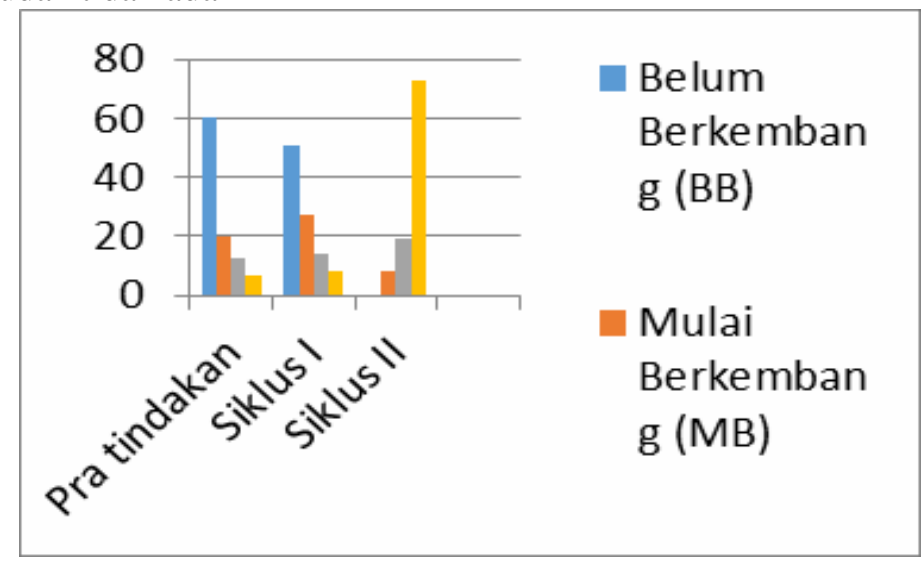

Grafik 1. Perbandingan Persentase Peningkatan Melaksanakan Model Pembelajaran Direct Instruction Berbatuan Media Kartu Kata Bergambar, Pra penelitian/Sebelum penelitian, Sesudah Pelaksanaan Peneleitian I, dan Sesudah Pelaksanaan penelitian ke II

Ada peningkatan hasil pada indikator Berkembang Sangat Baik (BSB) di mulai dari Pra tindakan ke sikllus I ada peningkatan $1 \%$, kemudan $65 \%$, sedangkan pada indikator Berkembang sesuai Harapan (BSH) di mulai dari para tindakan ke siklus I ada peningkatan 1\% dari Siklus I ke Siklus II ada peningkatan 5\%. Berdasarkan Gambar 2 grafik peningkatan kemampuan membaca permulaan, dapat dilihat bahwa ada peningkatan dari pra tindakan ke Siklus I sampai dengan Siklus II.

Pada akhir penelitian tindakan siklus II, Masih ada 8\% yang baru mulai berkembang (Radif). Hal ini disebabkan keberanian anak baru muncul dan kesiapan membaca mulai kelihatan, bukan karena faktor umur. Usia anak ini sudah mencapai 6 tahunan atau sudah cukup umur. Anak ini biasanya pendiam tanpa respon apa 2, dan tiap dia melakukan apapun harus di dampingi di beri pengertian pelan pelan.

Berdasarkan analisis yang dilakukan oleh peneliti, peningkatan kemampuan membaca permulaan ini dipengaruhi dengan model pembelajaran Direct Instruction berbatuan media kartu kata bergambar menggunakan langkah langkah Adapun keberhasilan tersebut dengan pengaruh model Direct Instruction berbantuan media kartu kata bergambar adapun langkah langkahnya langkah sebagai berikut: Fase 1, Estabilishing Set: menyampaikan tujuan dan mempersiapkan peserta didik. Fase 2, Demonstrating: mendemonstrasikan pengetahuan atau keterampilan. Fase 3, Guided Practice: Membimbing pelatihan. Fase 4, Feed Back: Mmengecek pemahaman dan memberikan umpan balik. Fase 5, Extended Practice: Memberikan kesempatan melakukan pelatihan lanjutan, dengan perhatian 
khusus pada penerapan kepada situasi lebih kompleks dalam kehidupan sehari-hari. Sehingga anak lebih terarah dan kondisi kelas lebih kondusif dan lebih fokus dan anak lebih senang dan menyenangkan dan lebih menarik perhatian anak.

Berdasarkan hasil refleksi, maka peneliti dan guru menghentikan tindakan pembelajaran membaca menggunakan model pembelajaran Direct Instruction berbatuan media kartu kata bergambar pada anak kelompok B3 di TK Aisyiyah Pembina Banguntapan, sebab sudah mencapai indikator yang telah direncanakan oleh peneliti.

\section{Pembahasan}

Setelah dilakukan penelitian siswa kelompok B3 TK Aisyiyah Pembina Banguntapan pada saat pembelajaran kemampuan membaca permulaan menggunakan Model Direct Instruction berbantuan media kartu kata bergambar, dua kali penelitian menunjukkan adanya peningkatan pada kemampuan membaca permulaan anak Setelah dilaksanakan penelitian II, keberhasilan yang direncanakan peneliti dapat tercapai dengan hasil yang baik.

Pada penelitia II, sebagian besar anak sudah mencapai kriteria keberhasilan dalam kemampuan membaca permulaan. Hanya ada 1 anak yang mulai berkembang dikarenakan belum memiliki ketertarikan atau kesiapan untuk membaca sehingga tidak memperhatikan guru dan sering mengganggu teman yang lain. Anak lebih sering bermain sendiri atau keluar kelas sehingga tidak memperhatikan guru dan masih sulit untuk konsentrasi. Dalam kemampuan membaca permulaan di perlukan kesiapan untuk membaca, dengan dasar itu guru mengajarkan anak akan lebih mudah untuk menerima apa yang diajarkan.

Anak tidak mengalami kesulitan lagi dengan menggunakan model pembelajaran Direct Instruction berbantuan media kartu kata bergambar, model pembelajaran ini bersifat berpusat pada guru. Dalam penerapannya guru harus mendemonstrasikan pengetahuan atau keterampilan yang dilatihkan kepada siswa secara langkah demi langkah menggunakan media kartu kata bergambar, misal cara membaca yang benar.

Dengan pendekatan Modelling pembelajaran langsung guru mendemonstrasikan dengan dibantu kartu kata yang ada gambar adapun langkah langkahnya sesuai urutan: Guru mendemostrasikan Mengucapkan bunyi huruf, membedakan huruf, menyebutkan benda yang mempunyai huruf awal yang sama, melafalkan kata dengan jelas dan anak memperhatikan dan menirukan seperti contoh

Dengan media yang menarik dan ukurannya lebih besar, akan lebih menarik minat anak dan sesuai dengan dunia bermain anak. Anak juga menjadi lebih aktif serta dapat memberi variasi dalam proses belajar mengajar guru karena sebelumnya hanya menggunakan media papan tulis dan LKA serta kegiatan pembelajaran membaca lebih efektif.

Pembelajaran membaca permulaan menggunakan model pembelajaran Direct Instruction berbantuan media kartu kata bergambar, merupakan pembelajaran langsung untuk penguasaan pengetahuan prosedural maupun keterampilan, di lakukan dalam bentuk permainan dengan menutup gambar kemudian menebak huruf/ kata yang ada di balik gambar dengan kegiatan tersebut anak menjadi lebih bersemangat, lebih antusias dan menimbulkan kepenasaran anak. Suasana kelas juga menjadi lebih kondusif, nyaman sehingga hampir semua anak menjadi lebih fokus Sehingga dapat konsentrasi anak.

Dengan menggunakan model pembelajaran Direct Instruction berbantuan media kartu kata bergambar, guru memberikan reward berupa bintang, anak menjadi lebih bersemangat saat belajar. Anak lebih kondusif saat menunggu gilirannya dan sudah lebih percaya diri saat mengucapkan bunyi huruf, membedakan huruf, menyebutkan benda yang mempunyai huruf awal yang sama, melafalkan kata dengan jelas. Anak yang sebelumnya suka diam tanpa ada respon jika di dekati sekarang mau memperhatikan dan antusias dengan tugas yang diberikan. Dengan diberi motivasi anak lebih percaya diri dan terus berusaha agar mampu melakukan dengan baik.

\section{SIMPULAN}

Berdasarkan hasil penelitian dan pembahasan, maka peneliti menarik kesimpulan yaitu pembelajaran dengan menggunakan Model Direct Instruction berbantuan media kartu kata bergambar mampu meningkatkan kemampuan membaca permulaan anak di kelas B3 TK Aisyiyah Pembina Banguntapan Bantul. Kesimpulan penelitian ini adalah sebagai berikut:

Kesimpulan proses, keberhasilan pelaksanaan pembelajaran kemampuan membaca permulaan 
menggunakan model pembelajaran Direct Instruction berbantuan media kartu kata bergambar, mengacu pada langkah-langkah sebagai berikut: (1) Establising Set yaitu menyampaikan tujuan dan mempersiapkan peserta didik memberitahukan tema pembelajaran; (2) Demonstrasing yaitu mendemontrasikan pengetahuan dan keterampilan dengan serta menjelaskan cara bermain dan memberi contoh; (3) Guided practice yaitu membimbing pelatihan dengan bergiliran untuk bermain kartu; (4) Feed back yaitu mengecek pemahaman dan memberikan umpan balik dan anak menyusun nya, anak bermain serta melakukan sesuai perintah dan contoh guru; (5) Extented Practice yaitu memberikan kesempatan untuk pelatihan lanjutan dan penerapan dengan mendampingi dan memotivasi anak apabila ada yang mengalami kesulitan. Melalui penerapan model Direct Instruction berbantuan media kartu kata bergambar, anak kelas B3 nampak antusias, penasaran, aktif, senang dan dapat mengikuti pembelajaran dengan baik, kelas terkondisikan dengan baik. Siswa dapat terbantu dan mudah dalam kemampuan membaca permulaan anak di TK Aisyiyah Pembina Banguntapan Bantul. Hal tersebut semakin mendukung tercapainya indikator keberhasilan penelitian ini.

Kesimpulan produk, Melalui penerapan model Direct Instruction berbantuan media kartu kata bergambar dapat meningkatkan kemampuan membaca permulaan anak di kelas B3 TK Aisyiyah Pembina Banguntapan Bantul. Peningkatan tersebut dapat dilihat dan dibuktikan dari adanya peningkatan persentase dari sebelum tindakan, setelah Sebelum melakukan tindakan, setelah dilakukan tindakan pada Siklus I dan setelah dilakukan tindakan pada Siklus II indicator Berkembang sangat Peningkatan dari pra tindakan ke Siklus I sebesar 7\% dan dari Siklus I ke Siklus II mengalami peningkatan sebesar 67\%. Anak yang berada pada kriteria Berkembang Sangat Baik sebelum tindakan/pra tindakan sebesar 0\%, pada Siklus I sebesar 7\%, dan pada Siklus II sebesar $73 \%$.

Dengan demikian peningkatan kemampuan membaca permulaan pada model pembelajaran Direct Instruction berbantuan media kartu kata bergambar sudah melebihi dari kriteria minimal $70 \%$ pada kriteria Berkembang Sangat Baik. Dengan demikian penelitian tindakan pada siklus II di nyatakan berhasil.

\section{DAFTAR PUSTAKA}

Arif, Z., \& Napitupulu, W. P. (1997). Pedoman Baru Menyusun Bahan Ajar. Jakarta: Grasindo.

Agus, S. (2009). Cooperative learning: Teori \& aplikasi PAIKEM. Yogyakarta: Pustaka Pelajar.

Blanton. (2002). Peningkatan keterampilan berbahasa Indonesia. PT. Raja Grafindo Persada.

Dalman, H. (2015). Keterampilan menulis. Jakarta: PT. Raja Grafindi Persada.

Dhieni, N. (2008). Materi pokok metode pengembangan bahasa. Jakarta: Universitas Terbuka.

Eliyawati, C. (2005). Pemilihan dan pengembangan sumber belajar untuk usia dini. Jakarta: Depdiknas.

Hasan, A., dkk. (2005). Kamus besar bahasa Indonesia. Jakarta: Departemen Pendidikan Nasional Balai Pustaka

Moeslichatoen, R. (2004). Metode pengajaran di taman kanak-kanak. Jakarta: PT Asdi Mahasatya.

Nurhadi, (1987). Membaca cepat dan efektif. Bandung: Sinar Baru.

Ngalimun. (2017). Strategi pembelajaran. Yogyakarta: Penerbit Parama Ilmu

Putra, S, (2008). Menumbuhkan minat baca sejak dini. Jakarta: PT Indeks.

Pritandhari, M. (2017). Implementasi model pembelajaran Direct Instruction untuk meningkatkan kemampuan berfikir kreatif 5(1), 47-56.

Rahim, S. (2008). Pengajaran membaca di sekolah dasar. Jakarta: Bumi Aksara.

Rahmawati, Y., \& Euis, K. (2010). Strategi pengembangan kreativitas pada anak usia taman kanak-kanak. Jakarta: Kencana.

Sadiman, A. S. (2008). Media pendidikan: pengertian, pengembangan, dan pemanfaatannya. Jakarta: PT. Raja Grafindo Persada.

Sudjana \& Rivai, A. (2002). Media pengajaran. Bandung: Sinar Baru Algesindo. 
Sulaiman, A, H. (1985). Media audio visual untuk pengajaran, penerangan dan penyuluhan. Jakarta: PT Gramedia.

Sugihartono, dkk. (2007). Psikologi pendidikan. Yogyakarta: UNY Press.

Susanto, A, (2011). Perkembangan anak usia dini. Jakarta: Kencana Prenada. Media Group.

Tarigan, H, G, (2008). Berbicara sebagai suatu keterampilan berbahasa. Bandung: Angkasa.

Undang-Undang Nomor 58. (2009) Tentang standar pendidikan anak usia dini 